\title{
某工場に於ける炙害の統計的 並に臨床的研究（下）
}

東大分院外科（主任 福田保助敉授）

若月俊一

（炤和 17 年 4 月 2 日受理）

\section{IX 災害の種類と損傷の部位}

一定工業に於ける災害の種類は，その物的原因の種類と共に大抵一定のものであら5事は想 像出來る。然しその各々の種類の頻度は必しる一定ではないであらう。何故ならば工場によつ て災害豫防の種々の工場內設借, 機械に附屬する保全装置, 勞働者の訓練等の程度が異るから である。蓋し災害の種類のあるものは炎害豫防の機械的設借の手段が完全に行はれ小ば其の頻 度を甚だ減少せしめ得るものであるが，他種の災害は之に關係なく主として勞働者の素質数育 乃至は疲勞等の個人的因子に關するのである。例人ば動力によつて運轉する機械に因る災害の 或るものは，ベルトやロープや进轉軸やギャー等に適當な保護裝置を施す事によつて，左漛な 種類の災害を革だ減少せしめる事が可能なるに反し，取扱中の工作機具や製品に原因する别種 の災害には上述の如き機械的保護裝置によつてはどらしても之を像防する事が出來ないるのが

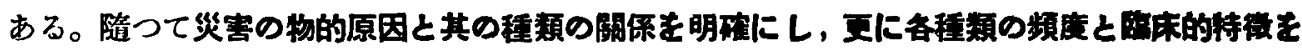
究明する事は炎害路防對策上必要不可缺事てある。

物的原因を以下の如く大分して，災害件數を調べてみると。

1）運轉中の機械に因るもの……..................................185 件

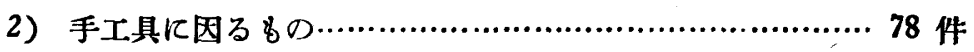

3）工具製品等の

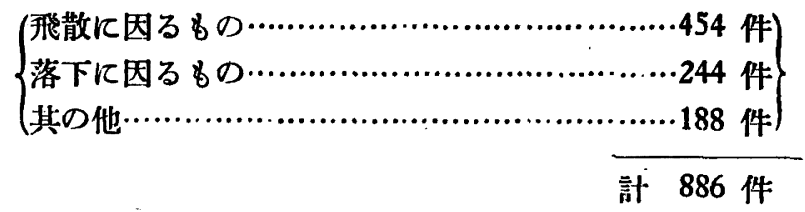

4）足場の不良に因るもの

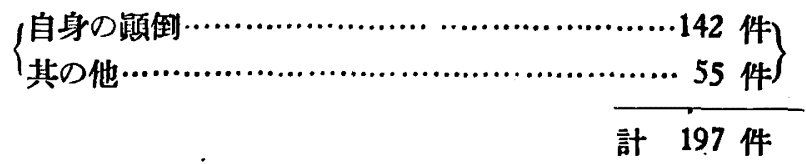


5) 火傷（電氣・磁飿を合む） 190 件

6) “其の他因る 119 件 このちち

1）「運轉中の椎械に因るもの」では”，旋盤操作に關する災害が最も多く，約半數を占めて

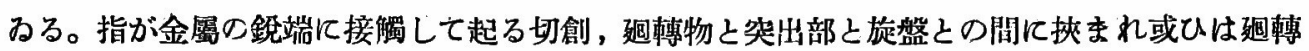
物に袖を卷をてまれて起る挫創，又はチャツッ(Chuck) の取りつけが惡くて品物が飛び出し たために起る打撲等々である。(但し最後の「品物が旋盤より飛び出して起る」のは(3)の「工 具製品に因る」の項に這入る)。次に多いのは milling (フライス盤操作)である。之はやはり 指を趈轉する蒛のあるカッター (Cutter) 几㒔れる事によつて起るのが多い。其の他べルト (belt)，ロープ (rope)，廻轉軸等の傅達機械に卷きて末れたもの。之の災害は一般に重傷が多 レのであるが，乙の統計には餘り多くながた。其の他グラィンダー（grinder）の砥石或ひは ホイール (wheel)，凡因る挫創，鍛冶の金鎚による指の挫減（「指をつぶされる」），プレス (Press) による指の切斷（「指を食はれる」）（第 15 圖）删盤による指の切創「指を制られる」

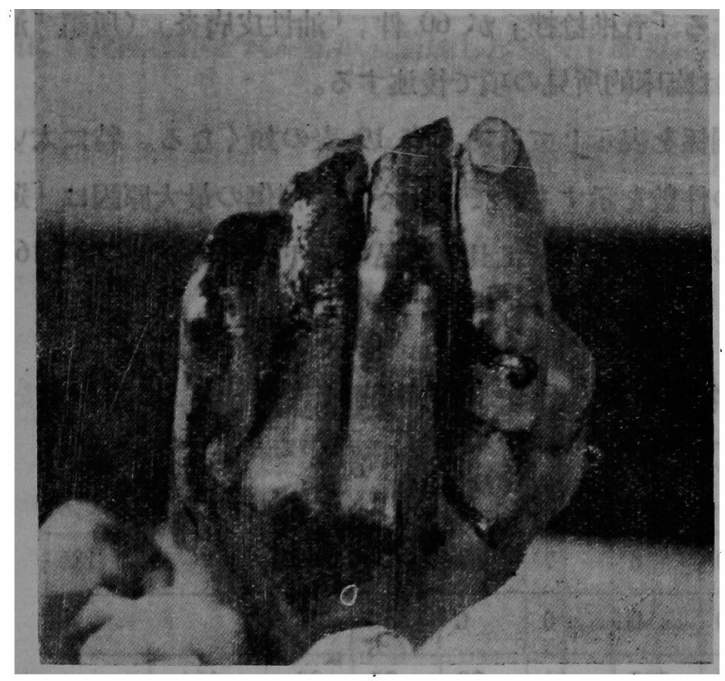

第 16 圖「プレス」に因る指の切斷
別に起重機（Crane）による比較的重き 災害, 叉モー夕ー（motor)，ローラー （roller）等に因る 8の等が主なものとし て列記される。

\section{この種類の㶤害は手殊に指に多く起る}

のは，殊に工作機械工場の荻害に於々て は甚だ特徴的なととで，後述する如くこ の種災害 185 件のうち 150 件は手の受 傷であり，更にそのうち 127 件を指が占 めてみるのである。

2）「手工具に因るもの」はシンマー， 錐，鯱，小刀等に因る 女ので，やはり 手殊に指の輕傷が多い。

3).「工具製品に因る」るのは此の統計に於んて最も多數を占め全災害數の $53.5 \%$ を占めて るる。之を 3 つに大別し，飛散，落下，其の他となした。「飛散」の部には前述の如き旋盤の

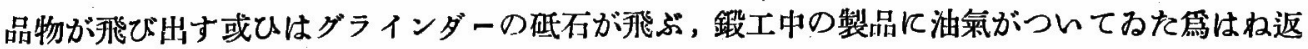

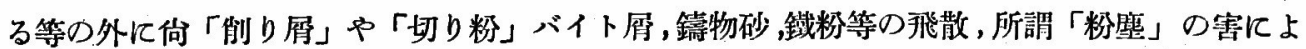
るものを含めた事索特記せねばなら外。後者は「眼內異物」症として甚だ多数を占める重要な 災害の原因である事は後述の第 19 表を見られたい。

次に工具, 製品の落下に因るものであるが, 之も相當多く而も中には霆々重症のものがある 


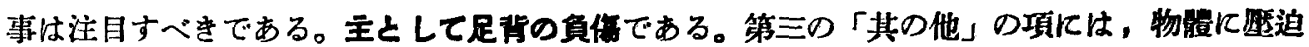

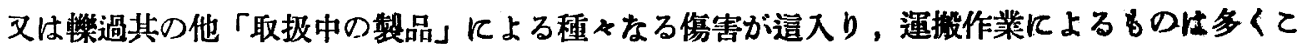
の中に含まれる。鑄型の枠に挾まれる，堆んだ製品が倒れて足が下敷になる，トロ (truck) に

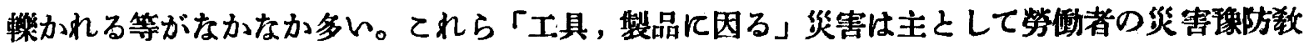
育の程度に關するものと云へる。但し疲勞，素質，就中疲勞は甚だ大きな意義を持つ。

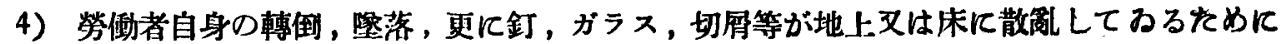

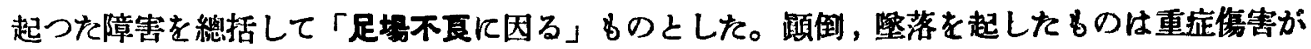
多いのはあらゆる統計の一致する所である。

5）「火侮」中には電氣災害，藥液に因る腐玲，爆發傷害をも合めた。火傷は鉻鐵，鉻鋼に上 るものが殆んど全部であつて多く足をやられる。第 19 表で見る如く次に眼の䅉害が多いのは 此の項に所謂「電氣性眠炎」を含めたからである。爆發例としては重油爈，カーパイト鱹等の 引火爆發が舉げられた。

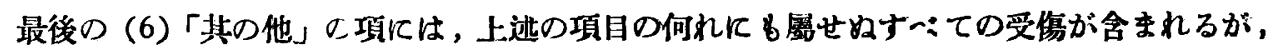

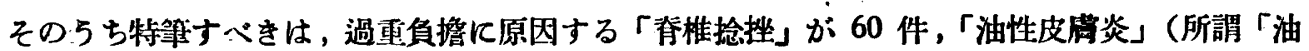
かぶれ」）が 12 件あつた。此らに就レては臨床的所見の項で後进する。

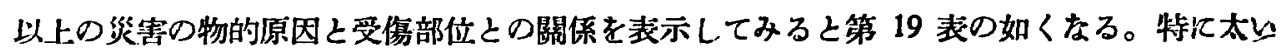
數字は各部位損傷に於ける最多原因と其の件數を示するので，例へば手損傷の最大原因は「運 轉中の機械」で之が 150 件あり，足損傷の最大原因は「工具，製品の落下」であり，之が 169 件に及ぶと云ふわけである。

第 19 表 災害の物的原因之受傷部位との關係

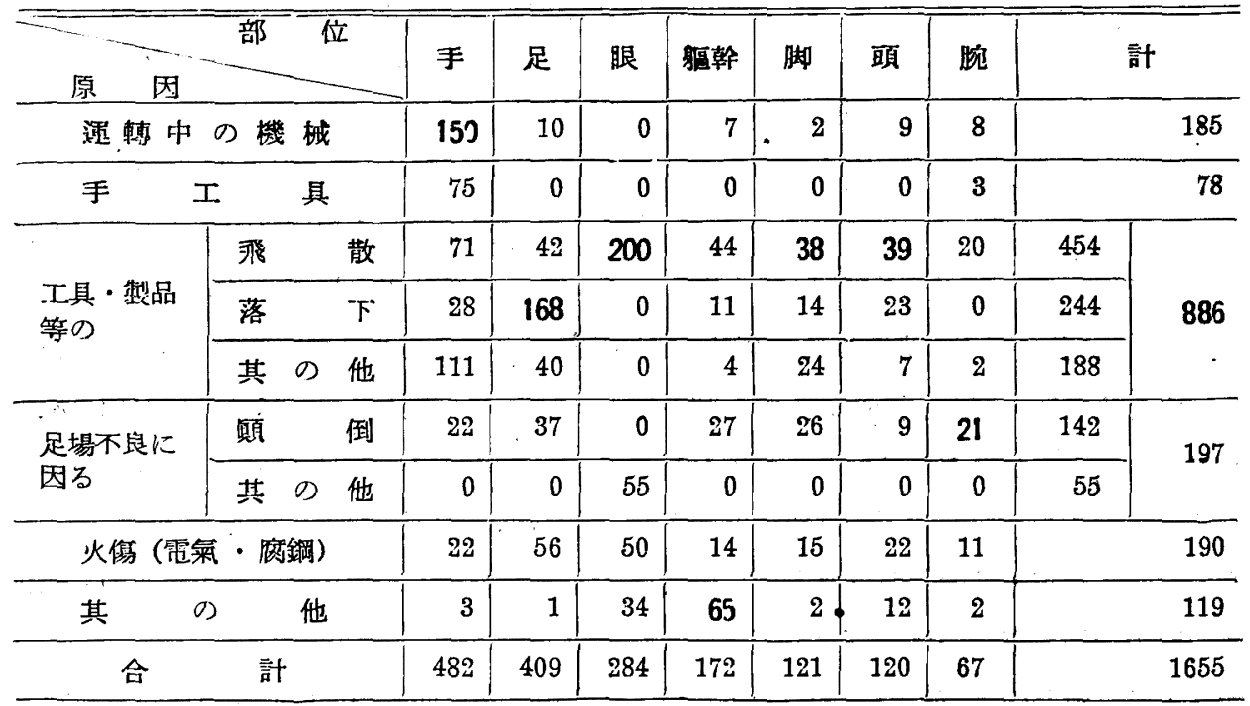


如何なる身觛部位に最も受傷が起り易いかと云ふと，此の一年間の統計に於いて

手受傷 482 件 $(29.1 \%)$

其の5 指受傷 362 件 (22.2\%)

足受傷 409 件 $(17.2 \%)$

眠受稘 284 件 $(17.2 \%)$

身區幹受傷 172 件 $(10.3 \%)$

脚受傷 121 件 (7.3\%)

頭受傷 120 件 (7.2\%)

腕受傷 67 件 $(4.0 \%)$

之を更に左右別にし，各部位受傷の分布面積を身體各部に擬へて作つたのが第17圖「部位別」

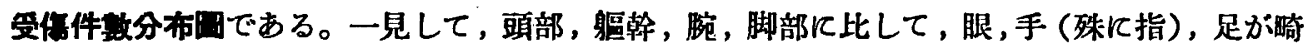
形的に大きいのが分るであら5。換言すれば，眼，手，足の受傷が他部の其れに比して甚だし く頻發すると云ふ事を明示してわる。手, 足の受傷が工場に於いて特に多い理由は物的原因の 項にて機械操作と云ふ點から前退した如くである。眼の損傷が多いのは，之は主として眼內異

「部位别，受傷件数分布圖

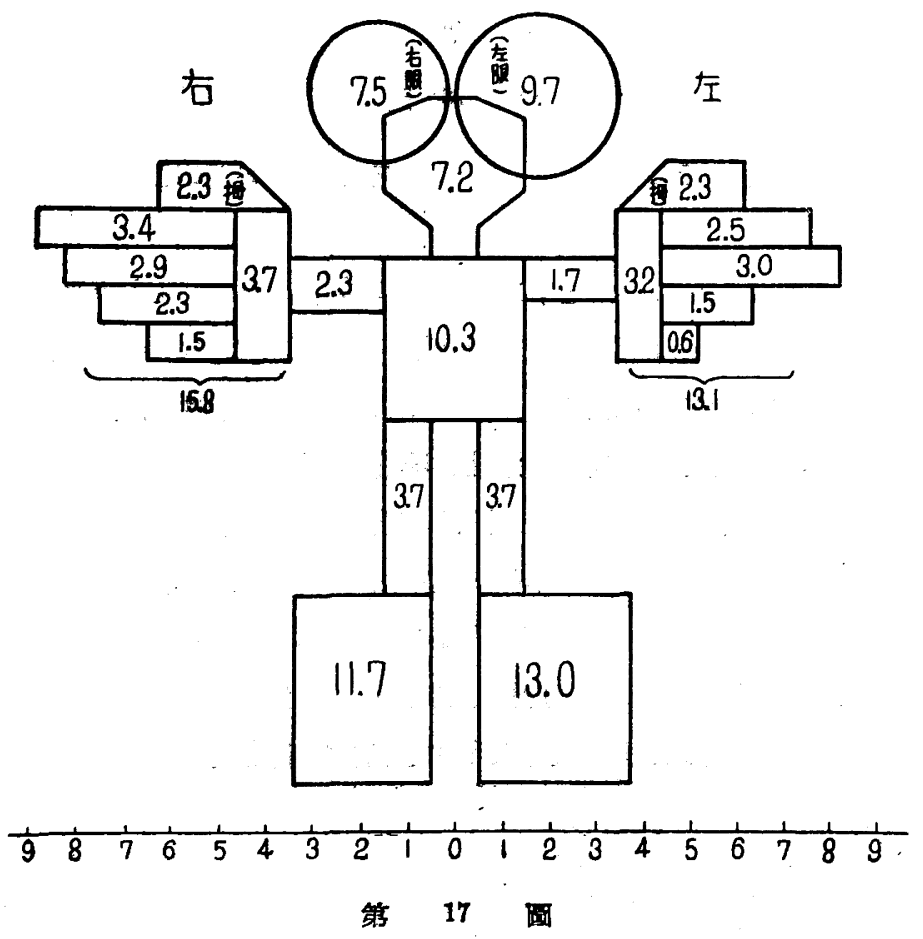


物であるが，異物が特に眼部を犯す之云ふのではなく，眼そのるのが特沉銳敏に損傷を蒙り易 レと云ふ理由に因るものであらう。

之らのものの左右別に就いて考へると，眼は左の受倁が多く左 173 件 $(56.4 \% \pm 2.84)$ 飞對 し右 134 件 $(43.6 \% \pm 2.84)$ で其の差は有意性（significance）を有してるる。之に反し足の受 傷も矢張り左方が多いけれども，(左 214 件郎ち $52.5 \%$ 土2.47）飞對し右 194 件郎ち $47.5 \%$

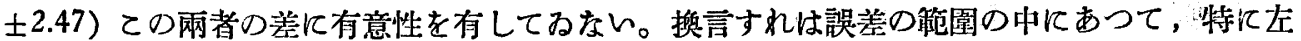
の方に受傷が多いと云ふ決論には直ちにならぬ。

一般に金屬工業に於ける統計では左眼損傷の方が多いと云はれてるる*。之は頭位と異物飛 來方向並に距離との關係上左眼に多々と考へられるのであつて，炏の第 18 圖は機械工の普通

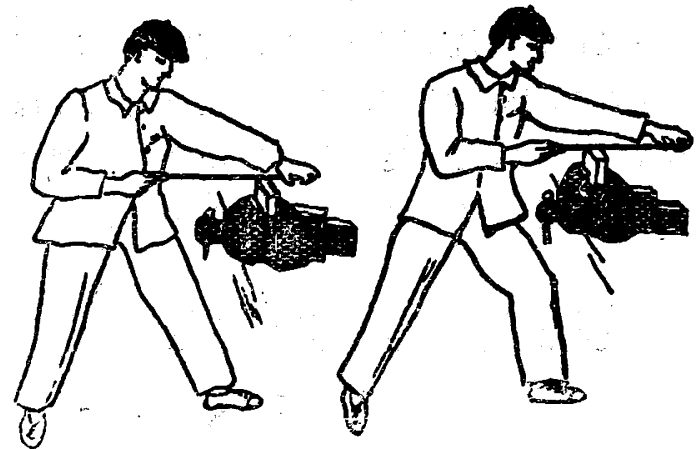

第 18 圆

の作業姿勢の型を示したものであるが，之によつて左眼，(左足)に比較的災害が多い理由が肯 ける事と思ふ。

次に手及び指の左右別に就いて云ふと，右手受傷 260 件 $(53.5 \% \pm 2.26)$ 几對し左手受傷は 226 件 $(46.5 \% \pm 2.2$ ) で其の差は辛うじて有意性を有する。，郎ち右手の方が左手より負傷を 受：易い。然らば各指に就いては如何と云ふに，各指の受傷件數は相當大きな開きを示して るる。之に就き $\chi^{2}$-Test を行つて其の梠違性を理論的に證明したのが第 20 裴である。更に 第 19 圖は各指の受傷百分率と $\pm 2 \sigma$ とを圖化して各々の百分率の差の有意性を一目膫然をら しめたものである。從來の報告にも**右示指，左中指等に災害が集中すると云はれて居るが誤 差論的登朋は行はれて居ない。兔に角第 20 表並びに第 19 圖に示された如く，指受傷件數の 分布比の大きさがでく大ざつぱに云つて拇指は別として他は各指の大きさに相礁して變動して みると云へない事はない。或ひはまた最も使用する指程怪我を受け易いと汽論するととも出來 よう。

* 田中謋、綜合腿科雜誌, 第 36 卷, 第 4 號。

** 唯揹一男, 外科, 第 4 卷。 
第 20 表 部位别指受傷件数率の比較

$\chi^{2}-$ Test

\begin{tabular}{|c|c|c|c|c|c|c|c|c|c|c|c|}
\hline \multicolumn{2}{|c|}{ 左右第何指 } & \multirow{2}{*}{$\begin{array}{l}\begin{array}{l}\text { 受侮數 } \\
(\mathrm{O})\end{array} \\
\text { (O) } \\
45\end{array}$} & \multirow{2}{*}{ 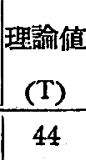 } & \multirow{2}{*}{$\frac{0-T}{1}$} & \multirow{2}{*}{$\frac{\frac{(\Omega-T)^{2}}{T}}{0.02}$} & \multicolumn{2}{|c|}{ 左.在第何指 } & \multirow{2}{*}{$\begin{array}{r}\begin{array}{r}\text { 受睢 } \\
\text { 数 } \\
(\mathrm{O})\end{array} \\
45\end{array}$} & \multirow{2}{*}{$\begin{array}{c}\begin{array}{c}\text { 理論値 } \\
(\mathrm{T})\end{array} \\
44\end{array}$} & \multirow{2}{*}{$\frac{O-T}{1}$} & \multirow{2}{*}{$\frac{\frac{(\mathrm{O}-\mathrm{T})^{2}}{\mathrm{~T}}}{0.02}$} \\
\hline \multirow{5}{*}{ 左 } & I & & & & & \multirow{5}{*}{ 右 } & I & & & & \\
\hline & II & 50 & 44 & 6 & 0.8 & & II & 68 & 44 & 84 & 13.1 \\
\hline & III & 60 & 44 & 16 & -5.8 & & III & 57 & 44 & 13 & 3.8 \\
\hline & IV & 29 & 44 & -15 & 5.1 & & IIII & 45 & 44 & 1 & 0.02 \\
\hline & V & 12 & 44 & -32 & 23.2 & & IV & 29 & 44 & -15 & 5.1 \\
\hline & & & & & & \multicolumn{2}{|c|}{$\Sigma$} & 440 & 440 & 0 & $\chi^{2}=57.0$ \\
\hline
\end{tabular}

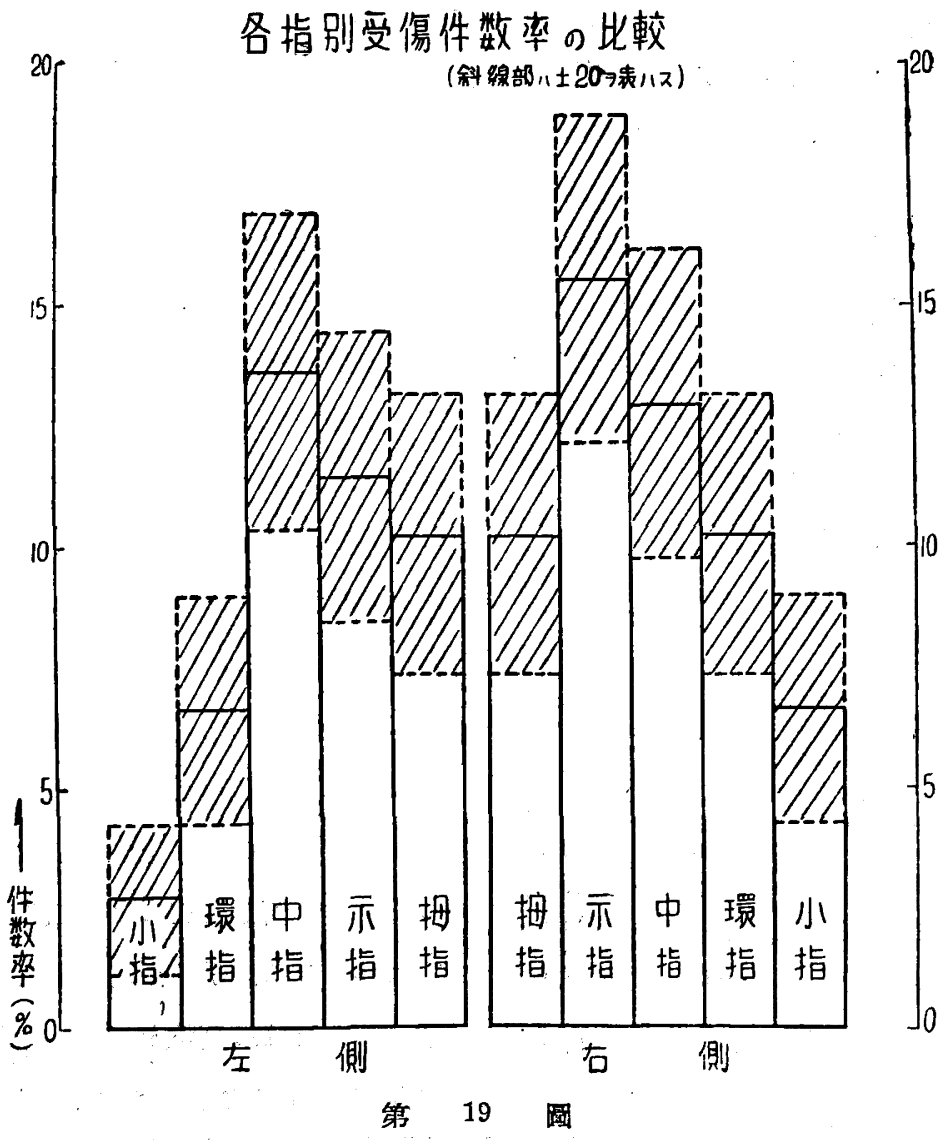




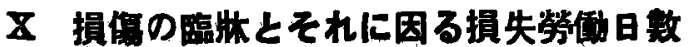

近年特に日支事變以來の我が國工業の夿躍的發展に伴つて，䠦休家側に於ける工場災害の研 究も次第に盛んになつて來たやうであるが，未だ多くの點に未開拓の稌地を殘してねると思は れる。察々たるての方面の文献のうちで，昨年 (昭和 15 年)，日本產䅈醫學協會發行の「工場 外科」は特篗に值する。之は主として內藤三郎博士等による八幡製鐵所に於ける重工業苂害の 臨佅經驗て基く諸諭文を䌂められたもので，所謂 Kümmel 氏病，䊂狀突起骨”折，腸管皮下損 傷，火傷及び外傷性神經症等の項目が舉げられた。又彩誌「外科」て於んては昨年 4 月及び 5 月號を各飞「手指損甥」及び「腹部皮下外偤」の特輯號となし，之ら題目下の研究論文を募集 揭载したが，何れも工場災害が次第に重要な社會的テーマよなりつ」ある現下の掞勢に順應す るものと見る可きであらう。手指乃至足趾の賣倁の如きは單なる小外科として從來一般に轻視 されて來た事は否めない。然し乍ら斯樣な手指，足趾小外傷が前章の統計表に於いて縷說した 如く如何に高々受傷率を持するものか，又以下本章にて示寸如く如何に多くの勞働日数老損失 するるのか，又如何に庫飞一寸した治療の不注意のために不愉快な後遺症狀の訴へが永く紣く かと云ふてとを知るならば，手足の如き部位が勞働力を商品とする人ネにとつてば致命的をも のである丈けに，其の能率の低下による損害は勞働者自身のみならす，工場更に國家にとつて る莫大なるものである。「單なる生物學的踇床」の與味の立場は，かかる現代の社會衙生學的見 地の重要性に一步席を绕るととこそ垶ましい。

向損失勞働日;數の統計的調查は從來我が國に於んては殆んぎ行はれす，只關東地方會災害統 計委員會*の 13,647 件に就いての報告があるから，以下隨所に於いて比較檢討寸る。但し篗者

第 21 表

\begin{tabular}{|c|c|c|c|}
\hline 椇傷部位 & 總受傷件數 & 全休業日数 & 重䈚崉 \\
\hline 手 & $\begin{array}{l}\text { 件 } \\
482 \\
\end{array}$ & 1,980 & 4.0 \\
\hline 足 & 409 & 1,551 & 3.8 \\
\hline 腿 & 284 & 448 & $1: 6$ \\
\hline 軀 幹 & 172 & $\begin{array}{c}\text { (死亡 1名) } \\
6,720\end{array}$ & $\begin{array}{r}(4.2) \\
39.1 \\
\end{array}$ \\
\hline 版 & 121 & 420 & 3,5 \\
\hline 頭 & 120 & $\begin{array}{c}\text { (死亡 2名) } \\
12,352\end{array}$ & $\begin{array}{c}(3.0) \\
103.1\end{array}$ \\
\hline 豌 & 67 & 291 & 4.4 \\
\hline 計 & $\begin{array}{c}\text { 件 } \\
1,587\end{array}$ & $23, \frac{\text { 昌 }}{446}$ & 14.8 \\
\hline
\end{tabular}

統計て於いては「死亡」 1 人に就き 6,000 勞働日の損失と見做して計算した事は第 3 章 ○ accident severity rate の項に 於々て詳迅 した如くである。

第 21 表は損榎部位別による全休業日數と 重篤萃を計出したるのである。括弧內の重篤 率は特に死亡による損失日數を計算しなんる のである。若し死亡による損失日数を除外し て考へるならば手の損傷による全損失勞働日 數 1,920 日は最高位を示し, 全苂害のそれの $35 \%$ を占めることとなり，前进の如き手指

* 關柬地方會災害統計委員拿，業醫祭，1940。 
損甥の重要性を寒書きするものである。身幹，頭部の損傷が甚だ高き重篤率を有するは，生命 維持に重要なる內睵や中樞种經を內包する部位である事を思へば登し當然であらう。眼提傷は 件数は莸だ多レがその重篤率は特に低く 1.6 亿過ざね。

\section{〔A〕手及び足の損伤}

工坋に於ける手及び足損傷の物的原因に就いては前章に於いて第 19 表を以て詳述した。即 ち手悠害全體のうち運轉中の機械によるものが 31\%，工具・製品に上るものが $59 \%$ と云ふ 割合なるに反し，足災害で恃特に工具製品の「落下」によるもののみが $41 \%$ を占め，運轉中 の機械に因るものの如きは殆んどないと云ふ特徵を有してるる。斯梯な原因的特徽は損倁の種

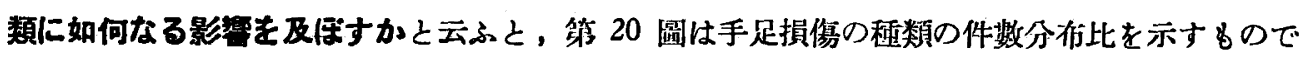

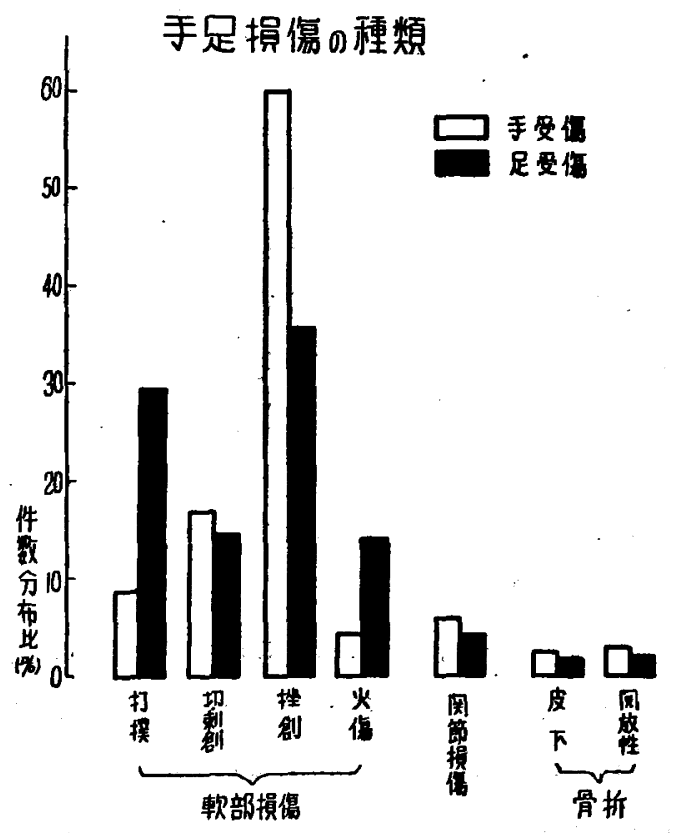

第 20 鶻 あつて, 挫創は手損傷の $5 ち$ 望に $60 \%$,を占 める。(岡田氏の臨佅報告にあつては $52 \%$ )* 足では 36\% を占めてるる。足損傷に於んて 打撲傷 $(29 \%)$ ，と火傷 $(14 \%)$ が比較的多

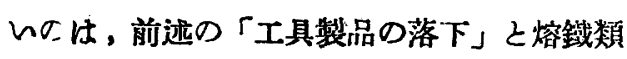
が主として足に「はねかかる、のに原因する。 骨折は共に $5 \%$ 內外（岡田氏報告では 13.5 \%)であるが，刺度の Rissfraktur 程度の る のは單なる「軟部損傷」の中に多數含まれて るるのである事實を忘れてはならない。 次に之らの損侮と平均休業日数（重篤赍） との關係を第 22 表にて見られたい。骨折の 平均休業日數が比較的少几（關東地方會のそ れと比して約 1/3-1/4) のは重㑺の件數が少 倳に因るのであらら。

手指外傷の處置については，一般的に云つ て適當なる指副木(Fingerschicne)を用ひて殆んど徽底的な保倠撩法を施すのが良いと思はれ

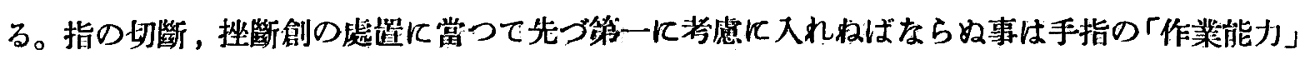
を出來得る限り保伱してやらねばをらぬ事，何とかして其の辰さと關節機能を保倞してやるや

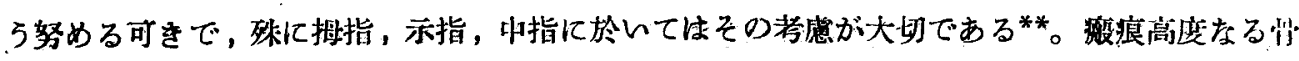
折指に於んても，長時日の後には相賞の程度に使用可能になるものであるから 1 糎す長く殘す

* 岡田正幸, 外科, $\mathrm{Nr}$ 4. 晿和 15 年。

** 岡田健一, 外科, $\mathrm{Nr} 4$, 昭和 15 年。 
第 22 表手, 足損傷の種類亡本均休業日數

\begin{tabular}{|c|c|c|c|c|c|c|c|}
\hline \multirow{2}{*}{\multicolumn{3}{|c|}{ 損傷 の種 類 }} & \multicolumn{2}{|c|}{ 手 } & \multicolumn{3}{|c|}{ 足 } \\
\hline & & & 件 & 本均休業日數 & 件 & 數 & 平均休箖日 \\
\hline \multirow{2}{*}{ 軟 } & 打 & 撲 & 42 件 & 2.4 日： & & 119件 & 3.5 日 \\
\hline & 切 & 刺 創 & 80 & 3.0 & & 58 & 2.8 \\
\hline \multirow{2}{*}{ 部 } & 挫 & 裂 創 & 288 & 4.1 & & 145 & 3.1 \\
\hline & 火 & 傷 & 21 & 4.9 & & 56 & 3.1 \\
\hline \multirow[t]{2}{*}{ 闆 } & 捻 & 挫 & 25 & 2.6 & & 16 & 4.5 \\
\hline & 脫 & 近 & 2 & 2.0 & & 0 & - \\
\hline 穊 & 開 & 放，性 & 0 & - & & 0 & - \\
\hline \multirow{2}{*}{ 骨 } & 皮 & 下 性 & 10 & 9.4 & 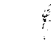 & 7 & 15.5 \\
\hline & 開 & & 3 & 11.0 & & 4 & 18.0 \\
\hline 折 & & 切斷 & 11 & 10.6 & & 4 & 25.8 \\
\hline 合 & & 計 & 482 件 & 4.0 日 & & 409件 & . 3.8日 \\
\hline
\end{tabular}

やうにエ夫してやるべきである。特に工場外傷に於いては創傷の化膿率が少い。之は農民に於 ける（特に農繁期に於ける）瘰疽の甚だ多きに比して甚だ注目すべき對热であつて，その原因

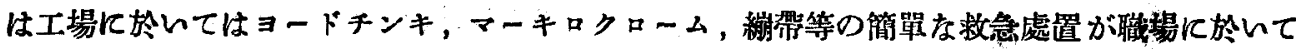
直ちに施され，且醫師起訪れる事が一般に甚だ早い事にあるのではなかららかと思ふ。何れに しても化膿率が少いと云ふ事は保存療法を行ふのに都合がよく，且肝油「ワゼリン」・ギプス緛 帶の使用は增々之を好都合ならしめるものである。

指骨骨折の5ち基指骨”骨折は，轉位が常に定型的で骨折末端が常に掌側に向つてるるが，之

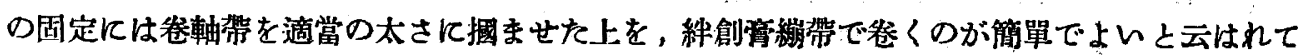
るる*(第 21 圖) が西田氏**は自家考察のギプ ス綪乖製の簡單な副子を用ひて, 又岡田健一氏は zuppinger 式の厚レプリキ板を用ひて之を患者に握らせる方法をよしとしてねる。何れにして も指骨骨折には特にその骨折端位と轉位の方向によつて，卷軸帶，絆創骨，「マスチジール」， ギプス，針金等を種ね工夫使用して，骨折端の整復固定を試みる事が必要であり(第 22 圖)そ れでも固定困難の場合は是非 Böhler 氏の鋼線率引を用ひねばならね。

轉位の極く少い指骨折に用ひる「指副子」も工夫によつて種くのるのが作られる。簡單なる のはボール紙，或ひは强い針金で指の大きさと形をかたをつたもの，或ひはての針金の中に網 を張つたもの等が豫めつくられ为意されてあらねばならね。

* 甲翌將明, 外科, $\mathrm{Nr} 4$, 昭和 15 年。

** 西田陶雄, 外科, $\mathrm{Nr} 4$, 昭和 15 年。 


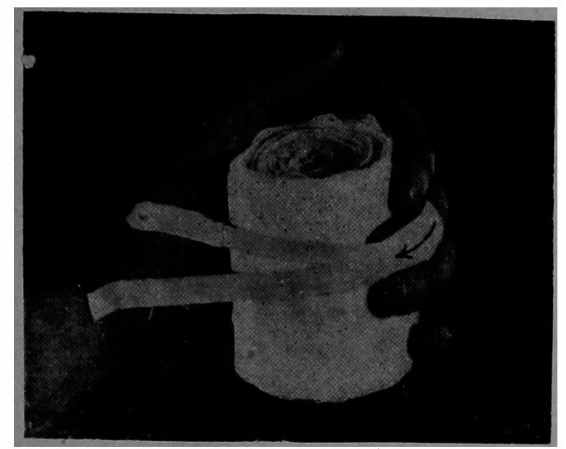

(A)

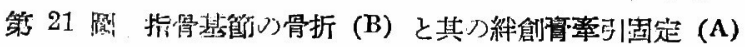

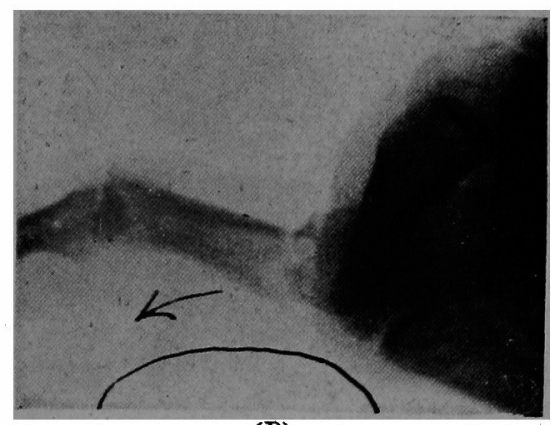

(B)

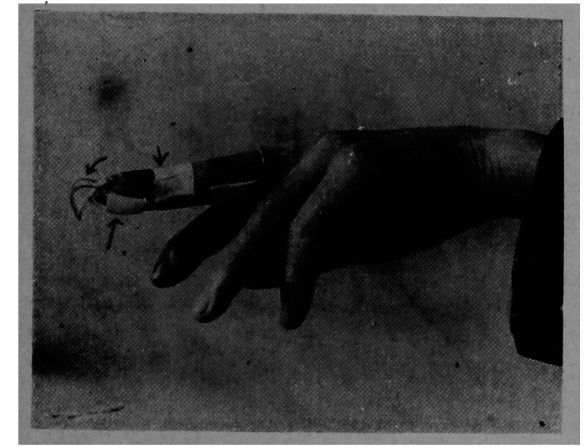

(A)

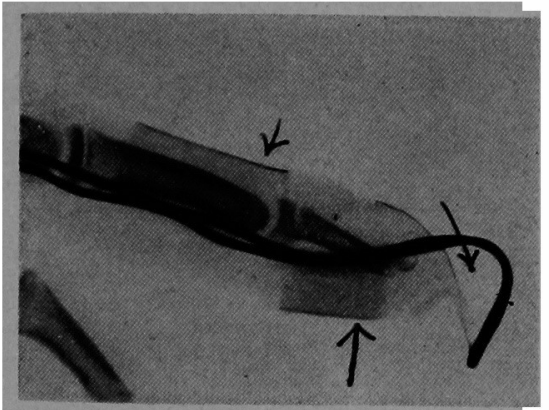

(B)

第 22 凅 (A)，(B)，指骨末笁の骨折の䊼創骨固定

掌骨，手根骨の骨折も上述の如く諸種の複雜なる機械による結果としてエ場には拯めて多い のであるが，筋肉，靬帶によつて周定せられてるる第著しい轉位を裴はさない場合があるねめ 諤診され易い。疑はしん時は必ずレントゲン檢䄳を行はないと，看過して單純な捻挫之誤り後 て諸種の症狀をのてす事が賽に多い。殊にベンネット氏骨折（第一掌骨基部の內掌面に起るも の）は案外多いもので，之を看過すると後に拇指の開指運動の障害を殘す事が多い*。

第 23 圖は milling 損傷で, 左拇指球を骨共に殆んど全部, フライス篮の Cutter で切斷さ

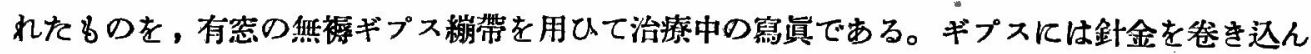
で拇指を率引してるる。第一掌骨はその基部に於いて完全骨折を起し，全くグラグラであり abduktion, Extension 老行ふ等及び腱は該部に於いて切斷されてみた。機械創に特有の挫隇・ 污染された創口部は之を出桃る丈け丁案に anfrischen し（更に硼酸・過「マンガン」酸加里混 合溶液 (3.0\% 硼酸水 $1 \mathrm{~L}$ 中に過「マンガン」酸加里 $0.8 \sim 1.0 \mathrm{~g}$ をよく混合したもの**) を以て 輕く洗淢する事もある。)切斷せる筋腱老縫合し，でく小さなョードホルムガーゼをドレナージ

* 栭中, 神中整形外科筃 1940 。

** 渡邉, 日本臨床外科醫會總會 昭和 16 年 11 月。 


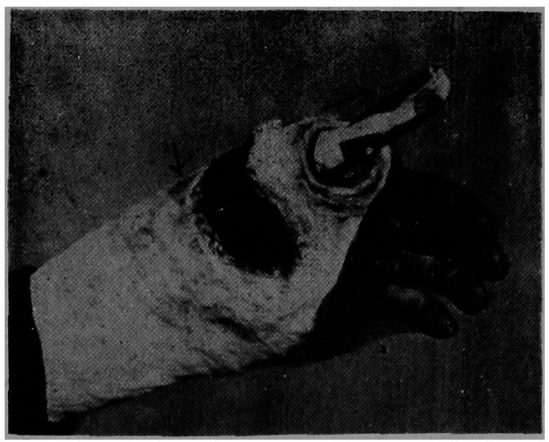

第 23 睘 第一掌骨の開放性骨折に於ける 拇指の毫引と有空無裖「ギブス」繃帶

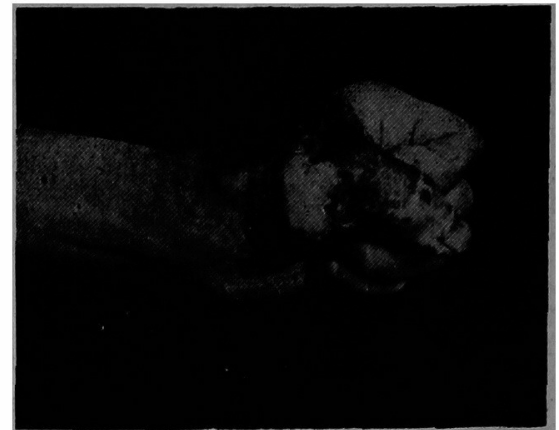

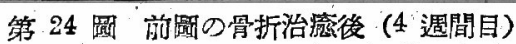
所謂 FaustschluB の可能狀態

そ㯰き，創は locker に縫合した。この第一掌骨骨折の固定には所謂 Bennet 骨折のそれと同 栐の工夫が要る。郎ち骨折の中樞端は背側飞轉位する傾向があるから，之を防ぐには寫椇に見．

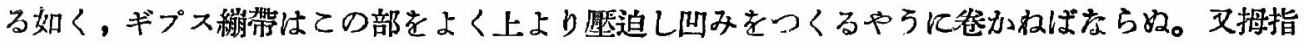
は外轉位の位置をとらせる。腕關箊を刺い dorsalflexion の位置に固定する事は，乙の關節の 强直を起さしめぬ雼に常に拂はねばならね注意であらう。'Oppositionsstellung 容易ならしめ る篇にギプスは出來る丈け掌部にかけぬ方が良いのであるが，乙の場合有密のため止むを得な

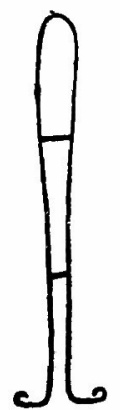

Bühier
Kien'e
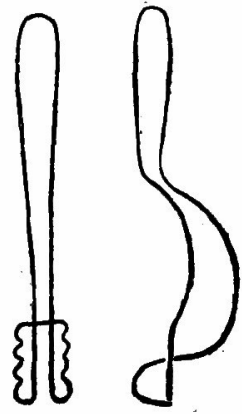

（据指用） (余の考案になる)

第 25 圖 指副木 (針金)

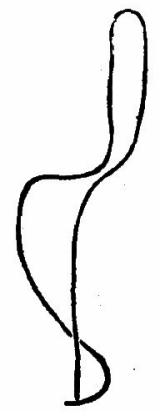

(小指用) る.

倘第 25 圖及び第 26 圖は指シーネで余の考

かつた。斯樣にして創は（ヨードホルムガーゼ は壁々日除去) 化膿せずそのまま閉鎖した。3 週目にはギプスを schaligに aufspalten して溫 浴, massage 等に上り，筋の機能恢復につ之 め, 特に m. opponens の機能恢復に注意を拂 つた。蓋し問題は拇指の機能恢復に在 り，特に m. opponens の機能は所謂 FaustschluB（暒 り杽を作る）に最も重要なものであるからであ 。
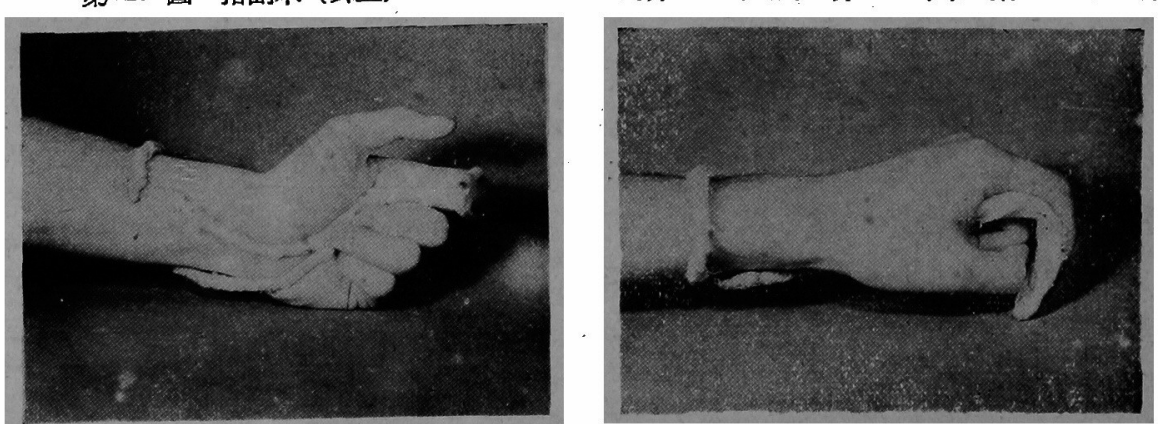

第 26 圖 予の考案の指副木 
菜したものであるが，之に就しては追つて研究した所を詳細に詮明發表するつるりである。

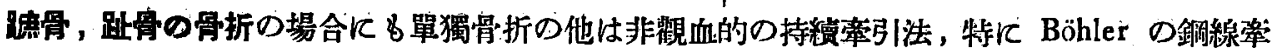
引法が推賞される。然し簡單に整復出来るものでは知張り指骨，掌骨の場合と同柡に種々の繃 帶林料金屬等を用ひての国定の工夫が必要である。此の際，趾骨殊几趾骨基篩部骨折では，骨 折末端が足背に轉位するのが定型であるから，之を注意して固定するのが眼目である。

\section{〔B〕㹸及び脚の損偪}

腕、脚損榎の種類別件数及び平均休業日數は第 23 表の如くである。之を第 IX 章の「災害 の物的原因と受傷部位との關係表」と比較してみるに，腕に於んては「足場の不良に因る」自 身の顧倒のための骨折，捻挫，打撲が最も多く，脚に於んては「工具・製品の飛散」に因る打 撲が甚だ多い。，前者に於いては顛倒の際て手を衝んて，所謂「定型的撓骨下端骨折」を起する

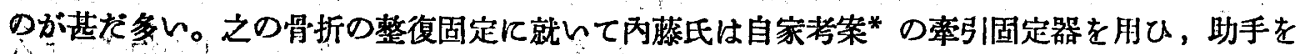

第 23 表 腕, 脚損傷

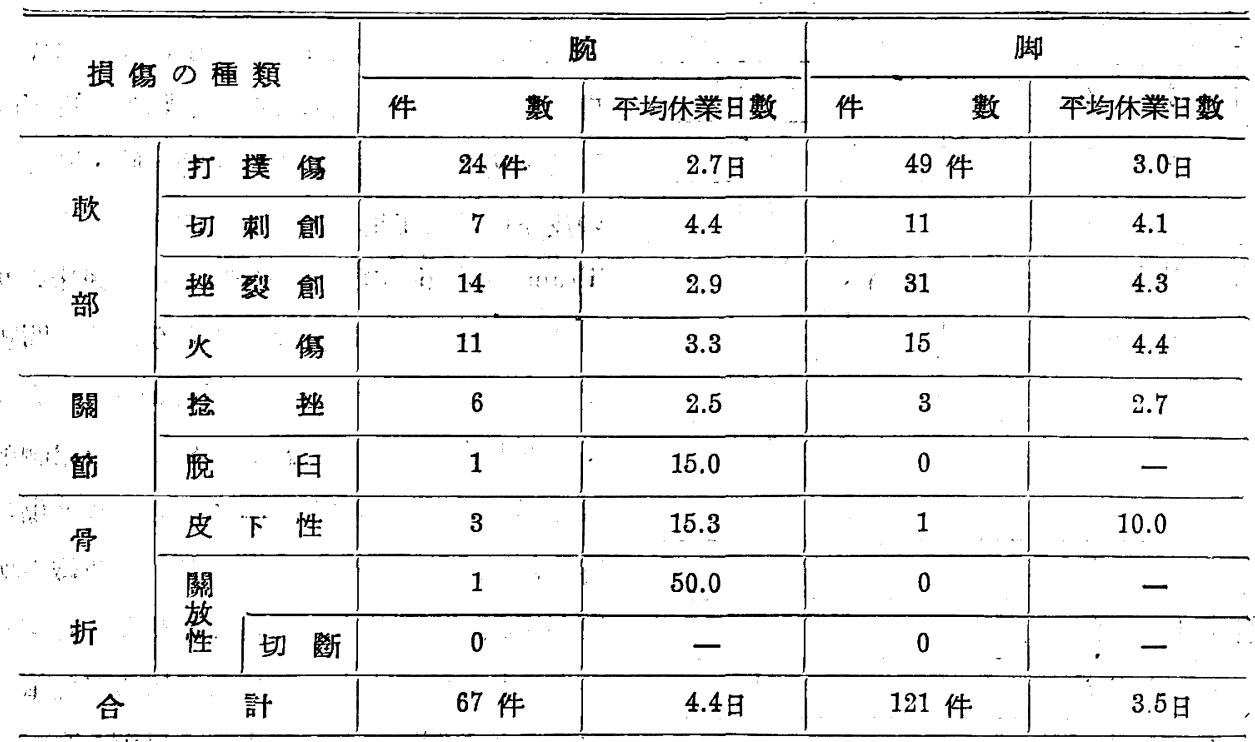

必要とせす。，又疼痛も少く 1 3 日の毫引固定にて甚だ良好を奏すると云ふ。

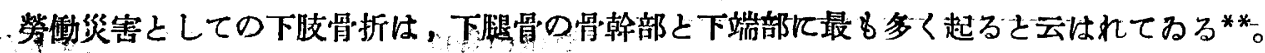
之らの治療には一般に銅線率引法又は Distraction が良效果を舉げると云はれてみるが，避當 な整復が施されたからは，隣接關節の强直，筋の萎縮を防ぐために massage と思ひ切つた早期 の運動, 瘾合前の早期步行が必要て，勞働者の骨折治療には特飞機能の恢復が主であつて，之

* 內輪，山中，日本整形外科學命誌，昭和 12 年。

** 池上, 井上, 石田, 勞働科祭, Ni 4, 昭和 16 年 
を損入ば如何に解剖的に又は美形的に立派であつても意味をなさぬ。步蹬をつけたキプス無啃 ギプス繳帶による早期步行は機能恢復と云ふ點から是非試みられねばなら将と信する。

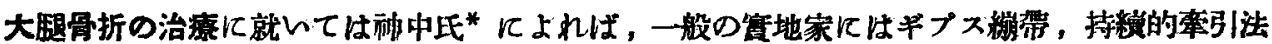

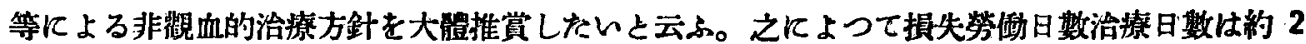

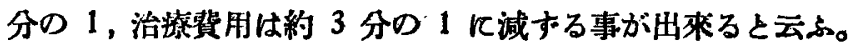

\section{(C) 船 幹 提 隹}

身區翰損傷の種類と件數及び本均休業日數は次の第 24 表の如くである。損傷種類は大體 2 つ に大分される。一は器械，器具並びに自身の轉倒による打撲（第 19 表參照）之他は過重負擔 に因る脊椎捻挫とも稱すべきものである。前者の打撲は特に胸部に多く，助骨嗗折，帽損傷等

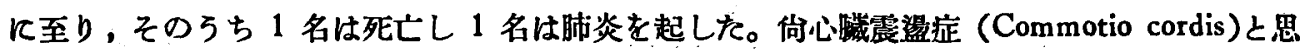
はれる者が 1 名あつた。Commotis cordis 亿就んては**當垡局より報告がある。之らは多く

第 24 表 軀翰損傷

\begin{tabular}{|c|c|c|c|}
\hline \multicolumn{2}{|c|}{ 損 傷 種 類 } & 件 & 平均休業日數 \\
\hline 打 & 撗佰 & 80 件 & 3.5 日 \\
\hline 切 & 挫 & 8 & 2.5 \\
\hline 火 & 傷 & 14 & 3.0 \\
\hline 內 & 肺椇稘 & $\begin{array}{c}4 \\
(1 \text { 名は死亡) }\end{array}$ & $2,033.0$ 日 \\
\hline 郝 & 腸管破裂 & 0 & - \\
\hline \multirow[t]{2}{*}{ 骨 } & 助 骨 & 3 & 26.7 \\
\hline & 零 椎 & 2 & 14.0 \\
\hline 折 & 鎖 骨 & 1. & 8.0 \\
\hline \multirow{2}{*}{$\begin{array}{l}\text { 㞑 } \\
\text { 椎 } \\
\text { 捻 } \\
\text { 唑 }\end{array}$} & 沜推 & 17 & 36 \\
\hline & 腰 推 & 43 & 3.3 \\
\hline \multicolumn{2}{|c|}{ 脊䯕震溋症 } & 1 & 31.0 \\
\hline \multicolumn{2}{|c|}{ 心歵震溋症 } & 1 & 5.0 \\
\hline \multicolumn{2}{|r|}{ 計 } & 172件. & 39.1 日 \\
\hline
\end{tabular}

運搬機义は運搬機に体り取扱中の物體による 打撲である。

䤷造工に多いよ云はれる，手に持つた棒が 自己の腹部を打つために起る，腸管の皮下破 裂は 1 例もなかつた。份肝・腎・脾・膀胱等 の皮下破裂も工場災害として問題になるが， Traumatologie の之等の分野で特に興味あり とされて居るのは肝外侮であらう。此の問題 に就いては autolytic Peritonitis の立場 から新しい研究がなされ，旰組織の自己融解 は生體に致死的影響を與へるから，肝外傷の 時には必扣開腹術を施行し, 且つ肝組織の壤

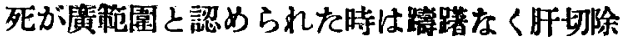
がなされねばならぬと云はれて居る***。筆者 自身もこの問題に就いて上述の見解老裹書き する如き若干の㙋驗を行つてるる。（未發表）

脊椎の骨折及び背椎捻挫とも稱すべきもの で, 過重負擔に原因してるると思はれるものに就いては一言を要する。胸椎最上部の棘狀突起 の骨折 2 例は所謂「スコップ」作業者病（Schipper Krankh`it）上して知られてるるもので

* 神中, 神中整形外科壆, 炤和 14 年。

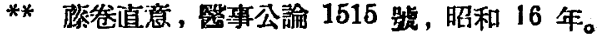

*** Buyce, F. F., and Mc Fetridge, E. M. Arch. Surg. June. 1937。 
わら5と思ふ。之については我が國では，上田氏*の報告がある。スコップ作柴，捱延作业等 に際する自家筇力の收縮に因る骨折で，多くは作業中笑然プツと云ふやうな音を發して，网局 胛间部に疼痛を訴へ作業を中止せさるを得なくなるものである。

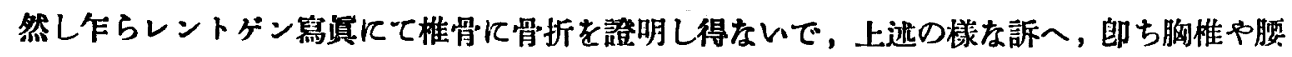
椎の疼痛乃至は腰痛吉訴えて來る患者が相當多い。骨の疲勞現象に上る所謂骨の過勞障害

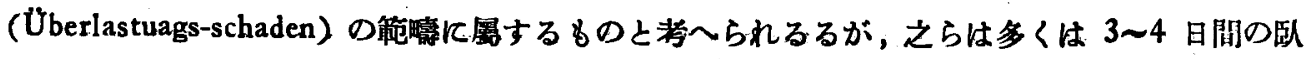
佅安静を命する事によつて恢復したのである。然し中には恢復までは隨分永くかかつたるのも あつた。ててで問題となるの性所謂外傷性脊椎炎であるが所謂 Kümmel 氏病と云ふるのは現

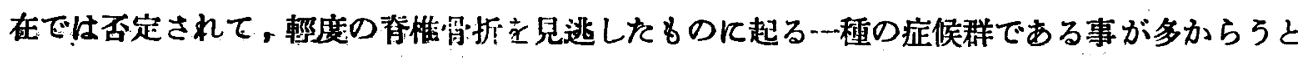
云はれてるる (內滕氏)。叉种中氏**云㤌れる如く arthritis deformans 之外傷との關係は甚 だ面倒なるので，脊椎の外傷性畸形性關節炎は悎かに有り得るが，之を真に外傷性之規定する には，外賃遖後には何の變化もなかつた事，少くも4週間以上經つて初めて斯かる變化がレン トゲン舄真の上に表はれて柬た事等が正確に調查されねばならねと云ふ。

\section{[D] 頭 部 提 侮}

頭部損傷の主なるものは工具・製品の飛散及び落下に因る（第 19 表參照）打撲傷及び挫創

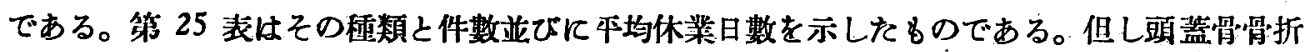
で死亡した 2 例は何れも「勞働者の慰落」に原因ナるものである。「坆落」は一般に重症災䈍 を惹起するものであつで**，一般に工場災害の死亡の 3 分の 1 以上は之に跌せられると云ふ。

第 25 表 頭部損傷

\begin{tabular}{|c|c|c|}
\hline 損傷の種類 & 件 & 平均休業日數 \\
\hline 打撲焪 過 & 20 件 & 2.2 日 \\
\hline 挫 · 切 創 & 67 & 2.7 \\
\hline 火 傷 & 22 & 3.2 \\
\hline 頍骨 閉 鑽 性 & 2 & 14.0 \\
\hline 骨折開放性. & (2 名共死亡) & $6,000.0$ \\
\hline 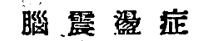 & 3 & 9.3 \\
\hline 頸 椎 捻 挫 & 4 & 2.7 \\
\hline 部 & 120 & 103.1日 \\
\hline
\end{tabular}

腦震璗症 3 例のうち 1 例はやはり自身の「榢 落」，他は工具・製品に因る打撲であるが、斯 樣な頭部損傷のあとに頑固な頭痛を訴える勞 働者が往ふあり，外傷性秗經症(Iraumatische Neurose）との鑑别が問題となつて來る。所 詡外傷性部經症儿は詐病的なものがあるか ら，Trepanation を行ふと良いと云けれてる る。叉山口氏 ${ }^{* * * *}$ 性かかる勞働者の「家庭內 情調䄳」を行つて日常素行の善惡を判定する 事が必要であると稱してるる。單なる「願望 性」の神經症には斯樣な方法も亦止むを得ぬ

* 上田, 九州醫學會誌, 昭和 12 年。

**神中, 骨折治珻罳, 昭和 15 年。

*** Vernon, accidentr and their Prevention. 1936。

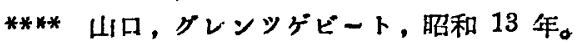




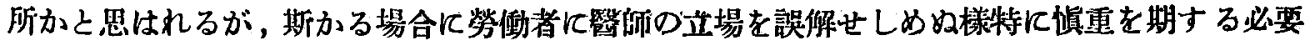
があららと考へる。

\section{〔E〕眼 損 傷}

眠提傷の種類，作數及び本均休拝日數江次の第 26 表の如くである。工具・製品等より作ら れる小破片や細粉に原因する角膜異物が崕倒的多數を占めてるる。アメリカの統計* によると

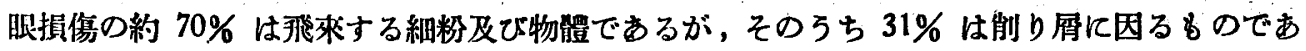
り，9\%は手工具に因るものであると云ふ。かかる角膜異物が勞働者の姿勢の關係で左眼に多

第 26 表 眼損傷

\begin{tabular}{|c|c|c|}
\hline 損傷の種類 & 件 & 平均休業日数 \\
\hline 角膜異物 & 227 件 & 1.5 日 \\
\hline 火 傷(腐刢) & 41 & 2.4 \\
\hline 䨓㚜性腿炎 & 9 & 1.8 \\
\hline 眼 球 打缮 & 7 & 1.0 \\
\hline 計 & 284 件 & 1.6日 \\
\hline
\end{tabular}

レ事は既に第 9 章に於いて述べた。田中氏** の統計的覞察によると異物の位置は左眼では 外下部に最も多く次レで內下部, 中央部の順 で, 上部は最も少レ。文右眼では內下部最も 多く次レで外下部, 中央部の順でやはり上部 には最它少レと云ふ。兔沉角平均休業日数は 傈かに 1.5 日であるが甚だ件数の多いエ場に

特有の苂害である。

電氣世眼炎は電氣揢接・瓦斯熔接等の弧光に因る眼障害であるが，本均休業日數は僅かに 1.8 日に過ぎ。原因は主として保護眼鏡の破損或ひは之の裝着の不適であるが，甚だしきは 裸眼の䍜で無暴な熔接作用をやうた者もある。約 7〜8 時间の潜伏時間を經て眼部の激痛が表 はれて來る。治療には温吪法が合理的であると云ぶ**。

\section{〔F]その他}

工場災害の火傷に就いては我が教室の****「タンニン」酸療法の良効果に關する報告がある。

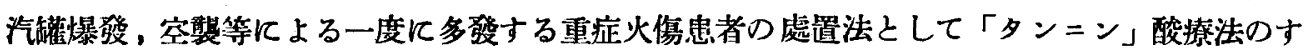
くれてるる事は吾が敎室の認める所であつて推賞をおしまない。

電氣災害としては 200 ボルトの電流が何れも同樣に右手より左足の數個所に通じ，各々當該 個所に電氣火傷を件つた電整症 2 例を經驗した。1 例はワイヤーから，他例はトタン板から通

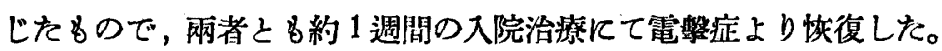

份當工場の研究部には「クロール」瓦斯による急性中毒症狀を呈するものが往々見られた。

\footnotetext{
* inonthly Lạ. Rev. March, 1923。

** 田中㘶, 綜合眼科雅誌, Nr 4, 昭和 16 年。

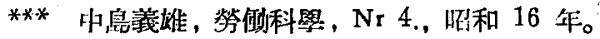

**** 永皇, 太田, 外科, 第 4 先, 第 7 啹, 炤和 15 年。
} 
勞働者は之を「ガスを食ふ」と程し，えに因る烈しい呼吸困難を逃れる篇に飲酒し，酪酊した 恰好で醫者を訪れ「モヒ」をろつて呂れと愁願し，吾ネを當惑させるのである。

份工場奖害 (Fabrikunfälle) と云ふよりは寧ろ工場疾患 (Fabrikkrankheit) と棌すべきも のと思はれるが，機悈油に因る急性皮虎炎（所謂「油かぶれ」）は可なりに多い。之の慢性化し たものに「痤瘡樣油疹」及び單なる「色素沈着」があつて之に犯されぬ旋盤工は少い位であつ た。排患部位は四肢殊に大煺伸側，前膊伸側，顏面等である。之に就いては昭和 14 年の日本 皮膚科學會に丸岡博士の宿題報告がある。

\section{XI 全篇の要約並ひに結論}

余は㭉縣「某製作所」（金濁・機俄工場）に於ける外科的臨床經驗を基とし，昭和 14 年 4 月上り昭和 15 年 3 月に至る迄の滿 1 ケ年に於ける苂害の統計的調查を試み從來ての種の統計 が陷り易い單なる羅列分類的続計法を出來る丈け避け工場苂害を根本的に理解せんとした。印 ち內面的に壮勞働者の個人性を問題とし，贸害頻發者に就いて研究し，外面的には現時の劇し い「生産速度」に就いて開明せんと心がけた。叉工場災害を統計學的に「誤差」と見做す根本 的憼念に就いて些か追求してみた。臨床的に Traumatologie としての工場災害に就いて特に 手指及足趾の損傷の重要性並びに治療法について私見を展開した。以上を要約すれば，

1. ての 1 ケ年の受傷件數率は勞働者 1 人につき $38 \%$ で甚だ高い。郎ち

災害件數率 $=380$

（災害頻數率關東地方會災害統計委員會讨定）

$$
=12.2
$$

(1923 年國際勞働會議決定)

2. 災害程度別反見ると (百分率)

$$
\begin{aligned}
& \text { 微症一 } 57.2 \pm 1.2 \text { (休菜 1～日） } \\
& \text { 輕症—-38.8 } \pm 1.1 \text { (休業 3 13 日) } \\
& \text { 重症一 } 3.7 \pm 0.5 \text { (休㱉 } 2 \text { 週間以上) } \\
& \text { 死亡- } 0.2 \pm 0.1
\end{aligned}
$$

で,「微症」が是倒的多數を占める。又

致死的: 非致死的 $=1: 500$

の比となる。

3、「休業日數別」災害件數分布圖を作つてみると，休業日數が多くなるに隨つて急速度に減 少する一つの定型的な曲線を得る。然るに災害はある意味で一つの「誤差」であると考へられ るから，若し休業日数が災害の程度を正確に表現するものと假定すれば，此處に所謂「誤差の 法则」が成立してもよいであらう。そてで各損甥部位別に，以上の曲線と，それより理諭的に 
計出した Quetelet 曲線とを比較拷察してみた。 $\chi^{2}$ 一Test によつてその一致を證明する事は

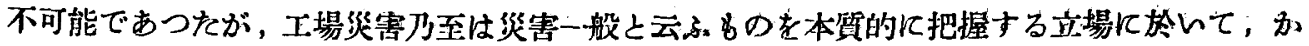
〉る着想による試みも其の誤㳣論的究朋の道程に於ける一つの基礎となり得るものと信ずる。

4. 休業日數と受傷件數とより accident severity rate を計算すると

$$
\text { 失日率 }=1,810
$$

(酷度)

重篤率 $=14.8$

(損失)

となる。但し死亡は 6,000 日の損失として計算した。

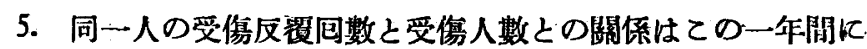
0 回 - 2896 人
1 回一 1008 人
2 包- 200 人
3 回—- 48 人
4 回一 5 人
5 回一 3 人

之よりPoisson 級数を用ひて，数學的傕率の立場より理諭值を計算し；之之上の福際值之 老對數表を以て明確に比較し，之を「受傷反復曲線」と名付けた。之を用ふる事て上つて所謂 「受傷傾向」(accident liability) 或ひはもつ之狭義の「受傷規性」(accident proneness) 者有 する者の存在を證明する事が出來る。更に之に $\chi^{2}$-Test を行つて，理諭值と筧際值との差を 有意義のものと證し得た。

以上の證朋は一般に受傷傾向者の存在を證明し得たのてあるが; E. Farmer の所謂 accident

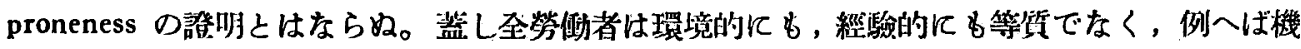
㭜部の勞働者は他職場の 2〜4 倍の受傷人数率を有するが, 隨つてまた受傷頻發者はそれ丈け 多レのである。

然るに之ら災害倾向者（刃は災害頻發者）のうち，1 ケ年て 4 四以上を反復した者を；臨佅 的に检查してみると，Farmer の云ふ如き感情的に不安定なる者或ひは利經的に不安定なる者 が慥かに多い。この中ょり肺結核の徽候を是する者も發見した。之らは受賃留性を有する者と 考へ，て差支へないと思ふ。但し受甥習性が固定したものでなく，慢性疲勞，結核，榮䓹不良等 几影響される事は十分注意さるべき事である。

6. 受傷傾向性乃至は受傷習性老有する者の存在老確定する統神學的方法のうち，一般に用 ひ得る謂はが概算的確定法とも稱すべきものに Newbo'd の表がある。之は非受傷省の百分率 と，每一人の受傷件数率とより，此の表走用ひて決定するのであるが，篚者はての表を一つの

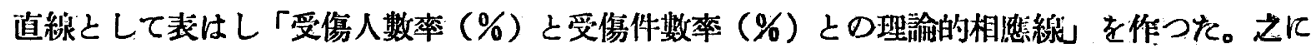
よつて概算的確定法を更に便にし得をと信する。

7, 勞跏者の雇别に受賃率を考察してみると; 本 雇- $37.1 \%$ 臨特㕍- $41.1 \%$ 生 徒 (見習少年工) - $33.4 \%$ 
て䠦時㕍が受傷傾向性多き事が登明された。

8. 更に勤続年限別に見ると

勤續 $1 / 2$ 年末涩者一一 $-99.1 \% \pm 1.1$

$1 / 2$ 年 1 年 $-78.2 \% \pm 2.1$

1 年 $11 / 2$ 年 $-49.4 \% \pm 2.2$

$11 / 2$ 年 2 年 $-24.6 \% \pm 1.8$

2 年以上 $-14.6 \% \pm 0.4$

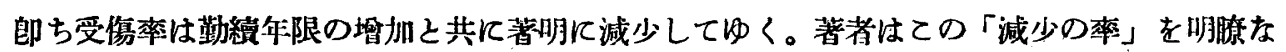

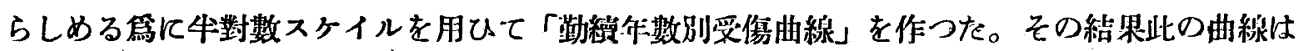

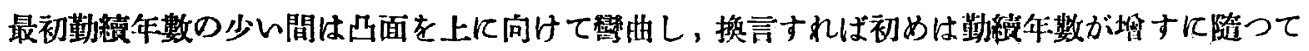
受傷は減少するのみならす「減少の率」る管加してみるのであるが，後になると（勤縝 2 作或 ひはそれ以上てなると）逆にての「減少の率」は減少してゆくのである。又之の曲線より全澧 の平均受傷件數率 $(38 \%$ ) 几相應する年數を求めて約 1.5 年を得る。節ち最初甚しき受賃倾 向性を有した新入者は的 1.5 年の勤續の後に初めて本均の受傷率值に到達出來ると云ふ事を意 味する。筆者は此の年數值を「本均受傷率年數」と呼ぶ。

9. 年鹵と受傷率との關係は

20 歲未滿 $-28 \% \pm 1.2$
20 歲 29 葴 - $41 \% \pm 1.2$
30 歲 39 歲 $-46 \% \pm 1.6$
40 葴以上 $-48 \% \pm 5.0$

で, 從來の報告と異り，20 歲未滿の者は反つて受傷率が少い。20 筬以上の間の者の受傷率の 變化は誤差の範圍內にあつて明膫でない。

10. 以上の雇別，勤續年限別，年令別の統計より逆に，災害倾向性甚だ强き「新入者」は年 䍅若幼なる者に非すして䀂ろ相當の年配者であり，所謂農村よりの「轉業者」「轉出者」であ る事を指示した。この點はての統計の有する一つの重要な社會的特徴である。

11. 春夏期，秋冬期の二つに大別して災害件數の時刻的分布圖を作つた。之によると午前の

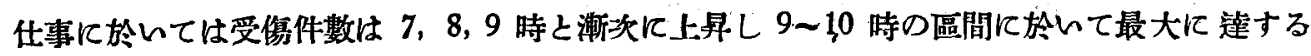
反し, 午後の仕事に於いては第 1 時間目に既に最大の籁圍の值に達する。又午前 9 時33 分〜 に 40 分の 10 分間の休憩が影響したと思はれる直後の受傷件數の低下が著朋に見られる。 之に反し午後の 10 分休喤の影響は明膫でない。之らの影響は何れる春夏季に著明である。

12. 畫業に比して夜業の受傷率は甚だ高い。以上時刻が受甥率に及保㨋種の著明なる影 響の說明は何れも「疲勞」の問題として取り擧げられた。但し之には「疲勞」の正確な證明は ない。 
13.「月别，受傷率曲線」によると夏秋が災害多く，1，2 月の極寒期は少い。之を更に分析 した「月別，㕍別，受傷件數曲線」及び「月別，主觀的原因別，曲線」と比較考察した結果秋 季に於ける受傷率の增㧈は，乙の期に於ける生產速度の强化と臨時雇の新入とに原因するもの と推論された。

「週日別」受傷件數分布圖によると，春夏期に於レては大䯣週末に近づくに隨つて受傷件數 は渐篔の傾向にあるが，秋冬期にあつては土曜日に至つて著しい減少を見を。

14. 災害件数を物的原因別に分けると，

a) 運轉中の機械に因る.もの……..............11.2\%

b) 手工.具に因る \&の….......................... 4.7\%

c）工具・製品の

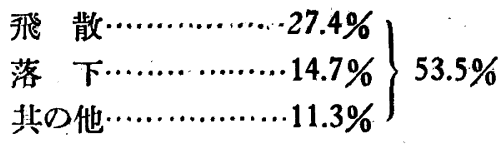

d）足場不良に因る

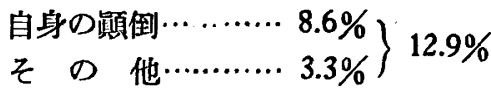

e）火傷（電氣・腐蝕）……...................11.5\%

f）其の他…................................. $7.2 \%$

であるが，それらの災害原因と受傷部位との關係は，

a）運轉中の機械に因るものの約牛數は旋盤操作に關するもので，主として手（特に指）の 受傷である。

b）手工具に因る ものも知張り手指の損傷而も微・刺症が多ん。

c）工具製品に因るものの5ち「飛散」に因るものは, 軀幹, 頭, 脚, 腕部の受賃が多い特 に「粉塺」となつて「眼內異物症」を起すものが夥しい。

工具・製品の落下に因るものは主として足の負傷である。中には展々重症のものがある。

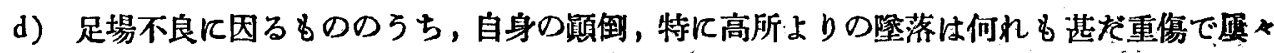
致死的である。死亡 3 例の5ち 2 例はての陮落に圆する。

e）火傷は鉻鐵，鎔銅によるものが主で，多く足部がやられる。

15. 如何なる身體部位に最も受傷が起り易いかと云ふと，

手 受 傷- $29.1 \%$

その中, 指受傷- $22.2 \%$

足 受 稘一 $24.7 \%$

眼 受 傷- $17.2 \%$ 
軀幹受傷- $10.3 \%$

脚 受 傷一 $7.3 \%$

頭部受傷—7.2\%

腕 受 傷- $4.0 \%$

之を更に左右别に分ち, 各受傷の分布面積を身體各部に擬へて「部位別受傷件數分布圖」な るものを作成した。

16. 受甥部位の左右別に就んてみると，

$$
\text { 手受傷 } \begin{cases}\text { 左側 } 46.5 \% \pm 2.26 \\ \text { 右側 } 53.5 \% \pm 2.26\end{cases}
$$

で，右㑡受傷の方がより多レ。各指に就いて云ふと，

$$
\begin{aligned}
& \text { 尖側拇指一 } 10.2 \% \pm 1.45 \\
& \text { 示指 }-11.4 \% \pm 1.51 \\
& \text { 中指- } 13.6 \% \pm 1.64 \\
& \text { 環指一 } 6.6 \% \pm 1.18 \\
& \text { 小指一 } 2.7 \% \pm 0.78 \\
& \text { 右側拇指- } 10.2 \% \pm 1.45 \\
& \text { 示指 - } 15.5 \% \pm 1.72 \\
& \text { 中指- }-12.9 \% \pm 1.60 \\
& \text { 環指一 }-10.2 \% \pm 1.45 \\
& \text { 小指- } 6.6 \% \pm 1.18
\end{aligned}
$$

であるから，大體使用する指程怪我を受け易いと云ふ決論が許される。

眼に就レては

$$
\text { 眼受傷 } \begin{cases}\text { 左側 } & 56.4 \% \pm 2.84 \\ \text { 右側 } & 43.6 \% \pm 2.84\end{cases}
$$

で，左側負賃の方が多レ。之は勞働者の作業姿勢の位置的關係から說朋される。

$$
\text { 足受傷 } \begin{cases}\text { 左側 } & 52.5 \% \pm 2.47 \\ \text { 右側 } & 47.5 \% \pm 2.47\end{cases}
$$

但し此の差は哭美の笘圍內であつて有意性がない。

17. 損傷部位と重篤率（平均休業日数）との關係は,

手損稘一 4.0 日

足損偣一 3.8 日

眼損傷一 1.6 日

軀幹損傷—39.1 日 
脚 損 䇰- 3.5 日

頭部損傷-—-103.1 日

腕損傷一 4.4 日

但し手，足の損傷は件數が甚だ多いから，全損失勞妝日數上しては何れ.も 2,000 日に近く， 其の生座能力の低下に及㤝す影響は輕視を許さない。

a）手及び足の損傷の種類に就いて受傷件數を比較するる

手損傷:

軟部損傷（打撲-8.7\% 切創-168\% 挫創一60.1\% 火傷-4.4\%）

關篩損傷- $5.9 \%$

骨. 折- $5.2 \%$

足損傷：

軟部提㑑（打撲-29.3\% 切創一 $14.5 \%$ 挫創-35.6\% 火倁-14.1\%）

關笽損傷 - $4.2 \%$

骨 折- $3.8 \%$

手指外傷の處置に就いては指シーネ應用による殆んど徹底的な保存療法を良しと考へる。郎

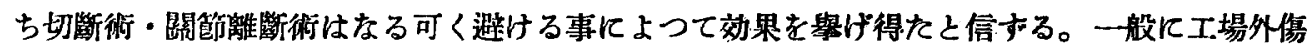
の創傷の化膿は少いものである。指骨骨折特に基・中指節部骨折は骨折末端が掌側に向つて轉 位するものが甚だ多いから，之の固定に對して，罕軸带，ギプヌ縌帶或ひはブリキ板の何れで

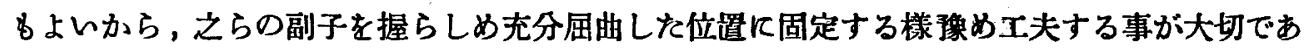
る。之に就いては當醫局に於いて行はれてるる二三の方法及び余の考案になる指シーネ（未發

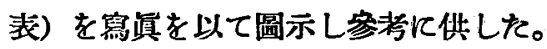

趾骨殊に趾骨基節部の骨折は之と反對に骨折末端部が足背に向いて轉位をするのが定型であ るから，上速の副子を反對の方向に用ふろ必要がある。

b）腕・脚部の骨折に際して特に注意されねばならぬ事は，解剖的又は美形的考虑よりる先

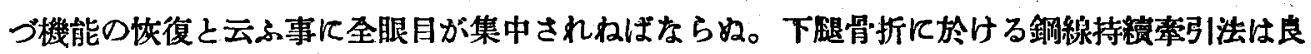
效果を舉げ得たが，特に思ひ切つた早期運動早期步行が必要であらら。

c）軀幹損傷の一は機械・機具或ひは自身の轉倒に因る打撲，特に胸部の打撲である。助骨

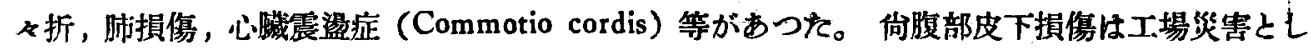
て重要であるがその5ち特に著者の興味を有してるる肝外賃に就いて若于の見解を述へた。他

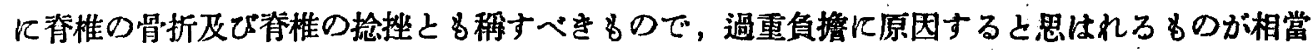
多く見られる。このうち2 例は胸椎最上部の棘狀突起骨折を發見し，所謂「ヌコップ」作帮者 病 (Schipper krankheit) と稱すべきものである。その他春椎に骨折老售明し得ないで腰痛, 胸・䃌椎痛を訴えて來るものが甚だ多い。Kümmel 氏症候群を表はすもの, arthritis deform- 
ans を伴へるもの等果して之が桼に當該外傷に關係あるものが゙うか炏定するのは甚だ難し ro

d）頭部損佰の重篤なるものは多く高所よりの管落に原因するのであるが，之の後遺症とし て頑固な頭痛を訴へる者には外傷性神經症との鑑別は嚴重に检查せねばならぬを同時に，之に

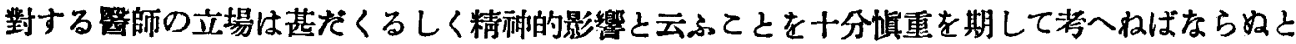
思はれた。

e)“眼損傷の種類と平均休拝日數との關係は

$$
\begin{aligned}
& \text { 角膜異物 (227 件)-1.5 日 } \\
& \text { 火傷(腐蝕)（41 件)- } 2.4 \text { 日 } \\
& \text { 電氣性眼災 （9 件）-1.8 日 } \\
& \text { 眼球打撲 (7 件) 一 } 1.0 \text { 日 }
\end{aligned}
$$

f） 200 ボルトの電流が何れる右手より左足の数ら所に通じを電氣桨害の 2 例は何れも約 1

災害因原調查表

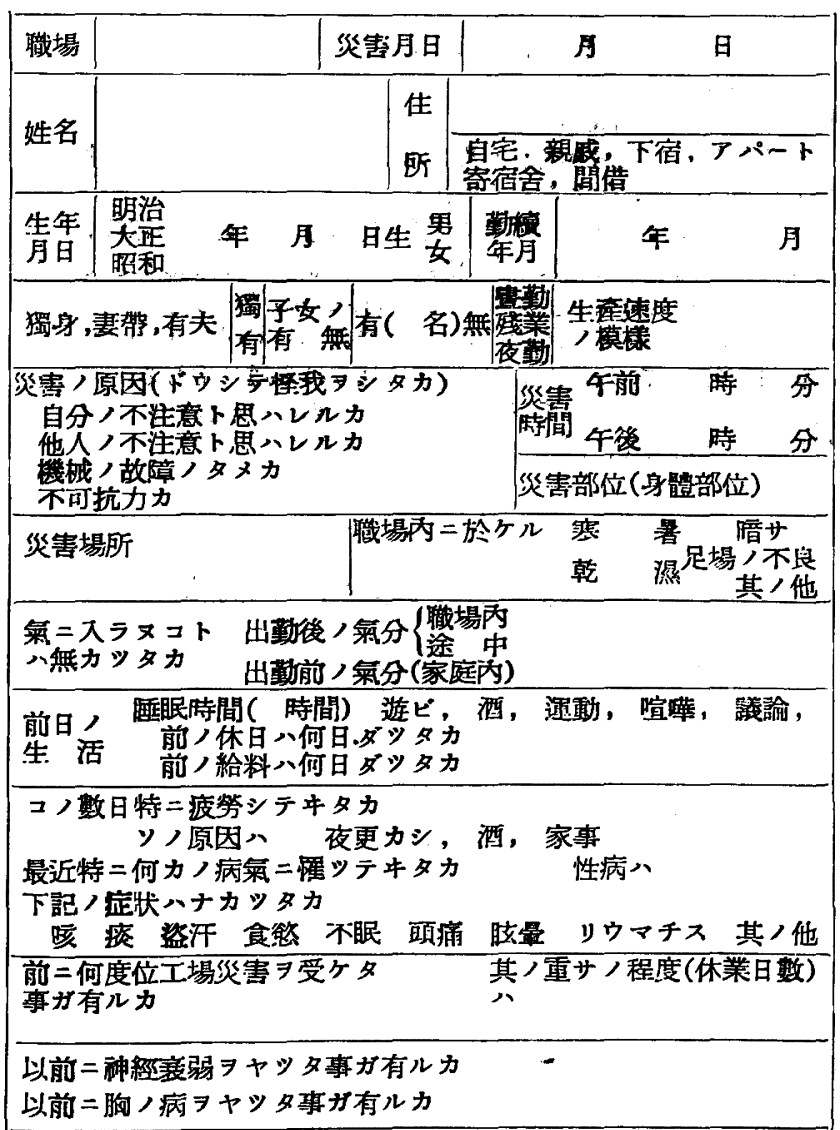
週間の入院治療にて電蒰症より 恢復した。 その他數多く診るものに, ク ロール瓦斯の急性中毒と機械油 几因る急性皮瘦炎がある。前者 は烈しい呼吸困難老訴人，後者

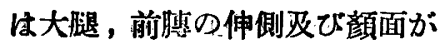
主として侵される。

g）最後に以上の統計的結果 の後に痛感された事は災害原因 の上り徹底的な研究の焉には， 從來の「會社の」所謂災害通知 票に賴る事なく臨朱家自身が 「自己の」災害原因調䄳票を作 つて, 自ら䛦療に際してその書 き込みに熱情を以て當らねばな らぬと云ふ事である。予自身が 作製し今後永く之によつて研究 を纘けてゆきたんと思ふ竾害原 因調查表は左のやうなものであ る。 


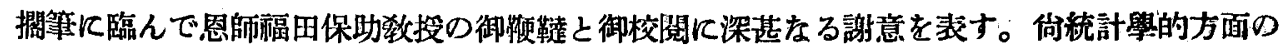
校閱を許された厚生科學研究所請師近藤忠雄氏，並びに榙種の有益な御忠告を睗はつた東大分 院腿科助手八束米吉君に深謝す。

又雜誌揭载にあたつて特別の御配虑を下された東大生理學教等請師奧保男氏に厚く御禮の意 を表す。

\section{主なる引用答考書及び引用文軒}

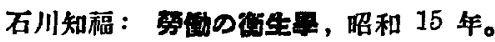

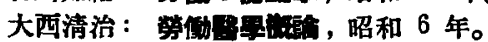

助川 浩：劳的简生矂話，昭和 9 年。

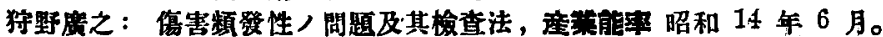

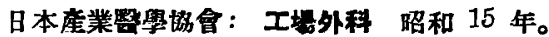

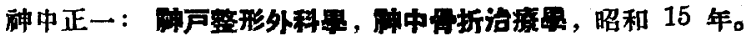

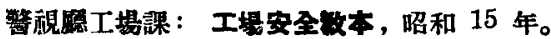

Constantin Kaufmann: Handbuch der Unfallmedizin I u. II, 1932

Frilz König u. Geurg Magnus: Handbuch der Gesamten Unfallheilkunde I, II, III, u. IV 1932

Lorenz Böhler: Die Technik der knochenbruchbehandlung I n. II, 1938

H. Matti : Knochenbruche, 1931

Zur Verth: Verletzungen u. Eiterungen der Hand, 1936.

E. Farmer: Causes of Accidents 1932.

H. M. Vernon: Accidents and their Prevention.

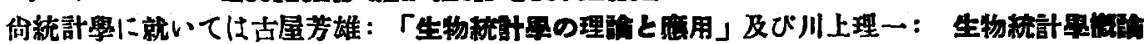

（上）上田常吉：「生物統計里」昭和 10 年，を主こてて用ひた。

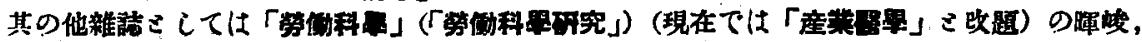

石川，平烃，八木，上野，山本氏等の諸大家の諸論交は大い熟誏致した。臨床雜声こして

は「外科」，昭和 15 年 4 月號の「手指损暘特辑號」からは大いに得万所があつた。

又 Reports of Industrial Fatigue Researches 各巻の諸册子中特1: Newbold, Osborn, Vernun 等の諸論交に貢ふ所が非常に多かつたのは本論交の却牲に見られる通りである。 之らの諸交献の勉强に就いて種々の御便宜をはかつて下さつた厚生科學研究所 教授石川知 福先生亚びに日本勞働科學研究所員勝木新次氏に深甚なら感謝の意を表す。 